\title{
Three Dimensions of Gender Mainstreaming in Economic Peacebuilding: Insights from Indonesia and Nigeria
}

\author{
Christelle Rigual
}

\begin{abstract}
Recent contributions to feminist security studies have pushed to reshape the postconflict women, peace and security agenda by taking the political economy of peacebuilding seriously. This chapter contributes to this scholarship by exploring how gender is mainstreamed in economic peacebuilding projects in Indonesia and Nigeria, and by providing a case study on how local beneficiaries have experienced one such programme in Indonesia. It analyses United Nations Development Programme (UNDP) and UN Women documents, and interviews with project officers and beneficiaries of an economic peacebuilding initiative in Indonesia, along three dimensions: the adoption (or lack thereof) of gender in international organisations' programming, the meanings and shapes gender takes in the documents and programmes, and the possible governmental effects of these programmes. The chapter argues that while gender has been widely adopted in international organisations' strategy documents, its integration into local programmes is uneven. It illustrates how gender representations and stereotypes can guide the design and implementation of programmes, with effects ranging from the further entrenchment of conservative gendered norms to the perceived improvement of status for some beneficiaries. Regarding the third dimension, or governmental effects of gender mainstreaming in economic peacebuilding, the chapter highlights the shift of funds to preventing/countering violent extremism programmes and the overreliance on neo-liberal economic frameworks and reasoning.
\end{abstract}

Economic reconstruction is one of the four pillars developed in UN Security Council Resolution 1325, joining the concerns of increasing women's participation in peacebuilding, enhancing their protection, and preventing sexual violence and war. In practice, however, a lot more attention has been paid to these latter concerns than to issues of economic reconstruction. This 
marginalisation is also reflected in feminist scholarship on peacebuilding, which has long explored political reconstruction in post-conflict settings at the expense of development issues. But many scholars have lamented that policies and programmes fail to integrate security and political economy in postconflict societies and have pushed to reshape what has come to be known as the UN's women, peace and security (WPS) agenda so that it takes the political economy of peacebuilding more seriously (Almagro and Ryan, 2020; Chisholm and Stachowitsch, 2017; De La Rey and McKay, 2006; Duncanson, 2016; Hudson, 2012; Rigual, 2018).

This paper contributes to this scholarship by exploring empirically how international organisations conceptualise and implement economic peacebuilding projects, and how such projects integrate gender. Drawing on desk and site research in Indonesia and Nigeria, it discusses United Nations Development Programme (UNDP) and UN Women projects in these countries. It also offers an in-depth case study of an economic peacebuilding project in Indonesia, designed by UNDP and jointly implemented by the UN Industrial Development Organization (UNIDO) and the International Labour Organization (ILO).

Because the implementation of the WPS agenda has rarely focused on economic peacebuilding, and because economic peacebuilding rarely puts gender at its centre, my entry point to the topic is from the bottom up. Rather than identifying gender-mainstreamed economic peacebuilding projects top-down, I discuss peacebuilding projects in two conflict-affected regions, that is, the islands of Maluku in Indonesia, and the city of Jos in Plateau State in Nigeria, and assess the extent to which and the way they consider economic issues, and the way they implement gender mainstreaming. The research design of the Swiss Programme for Research on Global Issues for Development ( $\mathrm{r} 4 \mathrm{~d})$ project Gender and Conflict (see Chapter 1 of this volume) sampled peacebuilding projects initiated by international organisations in each of these regions. I analyse these projects to understand whether and how they engage with gender and economic peacebuilding.

The chapter is organised into three sections. The first lays the theoretical foundation: drawing on feminist and peacebuilding literature, I suggest analysing gender mainstreaming in economic peacebuilding discursive formations along three dimensions. The first dimension addresses the extent to which gender has been mainstreamed in programmes. The second examines how gender is conceptualised in these programmes and what effects these conceptualisations can have. The third dimension explores the governmentality effects of gender mainstreaming in economic peacebuilding discursive formations; that is, the way gender mainstreaming is embedded in the power relations of economic orthodoxy and security politics. In the second section, I analyse 
documents and interviews with policy officers in international organisation (IO) headquarters to explore whether and how gender is integrated into UNDP and UN Women economic peacebuilding initiatives in the two case regions. In the third section, I draw on interviews with programme leaders in Jakarta and programme officers in Maluku and on focus group discussions (FGDs) with beneficiaries to provide a case study of a UNIDO/ILO 'Peace through Development' project implemented in the aftermath of ethno-religious conflict in Maluku. I conclude with a comparative assessment of the initiatives of different IO s in the two countries under consideration.

Peacebuilding is a complex field of discursive practices embedding theoretical assumptions, performative discourses, and programming agendas. Key questions focus on how peace is conceptualised, what are considered to be the root causes of conflict, and hence, what type of remedy can peacebuilding programming offer (Rigual, 2018). Liberal peace projects adhere to the assumption that democratic states tend to be more peaceful, and hence attempt to introduce democratic institutions into post-conflict settings (Doyle, 1986; Newman, Paris and Richmond, 2009; Paris, 2010). Following political economists, many conflict scholars focus their attention on economic development and struggles against poverty as key pathways to conflict prevention and post-conflict recovery (Collier et al., 2003; Krause and Jütersonke, 2005). The link between development and peacebuilding is now well established, but its concrete integration into programme designs and implementations remains particularly difficult.

Feminist scholarship has inadvertently replicated the division between democratic institution building and development. On the one hand, the field of Feminist Security Studies has flourished since the late 199os, with sustained attempts to 'gender' international relations (IR) security communities and their scholarship (Cohn, 2011; Prügl and Tickner, 2018; Sjoberg, 2009a; Sjoberg, 20ogb; True, 2011; 2016). These academic efforts, in conjunction with the lobbying of feminist peace activists, have led to the mainstreaming of gender into international security policy, in particular with the landmark adoption of United Nations Security Council Resolution (UNSCR) 1325 in 2000. On the other hand, scholars have cautioned against the potential pitfalls of these feminist politics in the Security Council: they fear that mainstreaming gender into security fields runs the risks of compartmentalising feminist knowledge, of co-opting such knowledge into security logics, and of progressively silencing 
the interplay between globalised militarised capitalism and internationalised armed conflict. As a result, scholars such as Carol Cohn, Claire Duncanson or Caitlin Ryan have called for a more systematic integration of political economy approaches into conflict studies and peacebuilding (Almagro and Ryan, 2020; Chisholm and Stachowitsch, 2017; Cohn, 2011; Duncanson, 2016).

Indeed, feminist activists and scholars have long sought to shape development practices, raising awareness of the complex web of gender relations in everyday lives and of the pivotal roles that women play in securing livelihoods. They have advocated for integrating gender into the design, implementation and monitoring of development programmes, in particular in post-conflict settings (Baliamoune-Lutz and McGillivray, 2009; Basu, 2017; Cornwall, Harrison and Whitehead, 2006; Greenberg and Zuckerman, 2009; Marteu, 2011; Reysoo and Verschuur, 2017; Verschuur, 2017).

To bolster their arguments, scholars have shown how deeply embedded norms of marriage, inheritance, land ownership and the different economic roles of men and women can foster or prolong conflict and further gender inequalities (Baliamoune-Lutz and McGillivray, 2009; Bowen, Hudson and Nielsen, 2015; Caprioli, 2005; Chinkin and Charlesworth, 2006; Forsberg and Olsson, 2016; Hudson and Matfess, 2017). In addition, they have pointed to the role of neo-liberal capitalism in putting pressure on land and resources, with the effect of rendering already vulnerable populations poorer and further at risk of violent conflict (Basu, 2017; Ramnarain, 2013; Reysoo and Verschuur, 2017; UNRISD, 2005). Anti-mining campaigns in Indonesia, the issue of Fulani herders deprived of grazing lands due to increased land appropriations in Nigeria (Rigual, Udasmoro and Achakpa, forthcoming), or mineral extraction for technology industries in the Democratic Republic of the Congo (Cohn, $2012,27)$ are only some examples of the impact that globalised capitalism is having on livelihoods and violent conflict. Feminist scholars are wary of these dynamics, and fear that a focus on gender and security might preclude an analysis of the deep-seated economic power relations at the root of many contemporary conflicts (Basu, 2017).

Inspired by contemporary assessments of gender mainstreaming (Moser, 2005; Moser and Moser, 2005; Prügl, 2009), this chapter adopts a threedimensional analysis of gender mainstreaming in economic peacebuilding. The first dimension of the analysis explores the extent of the adoption of gender terminologies in Io programmes. The second looks more deeply into the gender constructions produced in these discourses: how are masculinities and femininities framed, presented and reproduced? Are the aims, goals and implementation steps potentially transformative? The third dimension of the analysis draws upon the governmentality framework (Dean, 2010; Foucault, 
2004; Kunz and Prügl, 2019; Prügl, 2009 and 2011) to discern how patriarchal and other politico-economic power relations, such as neo-liberalism and security orthodoxies, are re/produced or hindered by gender and peacebuilding programmes.

I explore the three dimensions outlined by combining a discursive analysis of programmes implemented by UNDP and UN Women in Indonesia and Nigeria with an exploration of an economic peacebuilding initiative in postconflict Maluku. Indonesia and Nigeria share some macro specificities, which allow for interesting explorations of variations in Io programmes in communities that have been affected by similar conflict patterns. In particular, they share a history of colonialism, with independence gained at roughly the same time, followed in both countries by lengthy periods of autocratic rule and by democratisation in the late 199os. Additionally, these two countries have highly diverse populations and have experienced different types of conflict with similar patterns (resource-driven tensions, ethno-religious clashes, insurrectional movements) and that have been managed without UN peacekeeping operations (Krause, 2018).

We selected UNDP and UN Women as case organisations because they have a particularly active role in gender and peacebuilding programmes in the two countries. Extensive consultations with the r4d project team in Indonesia helped us identify an economic peacebuilding project that makes an attempt at gender mainstreaming and led us to select the UndP/Unido/ILO Pela Gandong project for the in-depth case study. The analysis entailed a combination of methodologies. First, I conducted a discursive analysis of existing UNDP and UN Women economic peacebuilding programmes in the two case countries. Second, I explored the way policy officers articulated and implemented the Pela Gandong project and how beneficiaries received the initiative.

Exploring similar types of programmes in different countries allows me to illustrate a little explored phenomenon: the widely different and idiosyncratic approaches adopted by agencies in their implementation of gender and peacebuilding programmes in light of the WPS agenda. The theoretical and methodological frameworks facilitate nuanced insights into how gender is being mainstreamed in economic peacebuilding practices, by exploring contrasting contexts and particularly relevant programmes. The intent is not to assess the work of the IO s under exploration, nor to draw definite conclusions on gender mainstreaming in the two country contexts. Rather, by contrasting peacebuilding activities in different contexts, and exploring a specific programme in Indonesia, I seek to instigate reflection on the processes through which programmes are gender mainstreamed and the way in which certain designs can generate (unintended) outcomes and governmental effects. The following 
section starts the empirical analysis with a focus on gender mainstreaming in peacebuilding programmes from UNDP and UN Women in Indonesia and Nigeria.

\section{Gender in Economic Peacebuilding Programmes: UNDP and UN Women in Nigeria and Indonesia}

UNDP and UN Women have a solid presence in Indonesia and Nigeria. This section analyses three specific aspects of these two agencies' peacebuilding programmes in the two countries: how aspects of economic reconstruction are integrated into Io gender-mainstreamed peacebuilding programming, how gender is conceptualised in such programming, and how such conceptualisations inform the implementation of peacebuilding programmes.

In Nigeria, the work of the UN Women section that focuses on WPS has three core components: 1) engaging women in peace and security, 2) mitigating violence against women and girls, in collaboration with United Nations Children's Fund (UNICEF) and the Ministry of Women Affairs, and 3) supporting the implementation of UNSCR 1325 at national, state and zonal levels. ${ }^{1}$ Not surprisingly for an organisation whose mandate is gender equality and women's empowerment, a first-dimension analysis illustrates that UN Women has thoroughly adopted gender mainstreaming terminology, developed associated policies, and implemented related programmes. But with regard to peacebuilding, the work of the Nigerian WPS section focuses principally on the pillar of participation, with a project on 'Democratic governance and women's participation in politics'. While issues of economic reconstruction are not salient in this project, it is useful to explore it more deeply in order to gauge UN Women's approach to gender mainstreaming.

UN Women operates from a highly bottom-up perspective in terms of the design of its projects, conducting consultations with communities to gauge the needs, challenges, and best ways to address existing gaps in women's participation in peacebuilding (Achakpa and Onyesoh, 2018). One action the officers have been particularly proud of is the collaboration with traditional councils in northern Nigerian states. Traditionally, these informal but highly respected decision-making institutions at the sub-state level included only men. As the UN Women programme officer explained, this situation reflects local gender norms and a patriarchal culture:

1 Interview with programme officer, UN Women, Abuja, 16 February 2018. 
For example, in the three states in northern Nigeria, women are supposed to be quiet, they are not supposed to be vocal, they are not supposed to speak before men and all that. And that is why the traditional institutions don't have provisions for women. So when there are violent conflicts in a particular state, it is the men that would sit, have a discussion, take decisions on what they need to do, without actually looking at the gender dimensions, without actually looking at the perspectives of women and how those conflicts affect women, without considering the fact that women have a role to play in peacebuilding processes. So they are ignored.

Interview with programme officer, UN Women, Abuja, 16 February 2018

It is thus clear that in northern Nigeria, UN Women works in a context where patriarchal gender norms infuse all aspects of peacebuilding, and where men are represented as the legitimate decision-makers regarding conflict management in their communities. Responding to this context, UN Women conducted rounds of discussion and awareness-raising activities directly with local chiefs, and enjoyed considerable success with these engagements (Achakpa and Onyesoh, 2018):

So we engaged the institutions very well, in three states in the north [...], and we succeeded, to a large extent. Because in these three states, now they have women appointed in their traditional councils. In Plateau when we started, there was zero, but today we have ninety-six women in the four LGAs [local government areas] we work in, who are now members of the traditional institutions and also advisers. And what that means is that any time the traditional institution will sit to take decisions, those women will be represented, and those women will bring their voices into those issues. That has given them the space to contribute to peacebuilding.

Interview with programme officer, UN Women, Abuja, 16 February 2018

So while gender is thus included in the thinking and strategising of UN Women Nigeria, the focus on political participation foregrounds a concern with women rather than gender relations. In other words, regarding the second dimension of my analysis, gender mainstreaming is mostly equated with the participation of women. The modality of implementation has been to focus on women's participation and training, although there are also efforts to include men in the programmes, in particular strong gatekeepers. The project can claim a quantitative success on the basis of the number of women included in traditional councils. This is a remarkable achievement, which significantly changes an 
influential patriarchal institution. But the narrow focus on women also needs cautious attention, given existing critiques that warn against an essentialisation of women as natural peacebuilders and a tendency to instrumentalise women for purposes of peacebuilding that may forget goals of gender equality. Indeed, the inclusion of women in traditional councils leaves open the question of the roles women get to play in these councils. Are they tokens, or are they allowed meaningful participation?

With its exclusive focus on women's participation, the case of UN Women Nigeria exemplifies, at the time of the research, the very compartmentalisation of gender knowledge -into peacebuilding as a matter of politics, on the one hand, and as economic development on the other- criticised in the feminist literature. It also illustrates the difficulty of integrating these highly compartmentalised fields.

While UN Women embraced a gender agenda and foregrounded political participation in the implementation of WPS, UNDP Nigeria prioritised poverty alleviation and economic growth with little attention to peacebuilding. It also struggled to achieve the first dimension of gender mainstreaming - that is, its integration into programming from the start. For instance, in a project that sought to encourage access to international markets for small-scale agribusinesses, gender issues seemed to be acknowledged only to be subsequently dismissed. Programme documents deplore that in an initiative focusing on the production of cassava, which is dominated by men, 'gender may be an issue and the sector may not fulfil the requirements of UNDP to contribute to gender equity'(UNDP Nigeria, 2013, 23, author's emphasis). This assessment illustrates that UNDP does not fully mainstream gender in all its programmes. Moreover, regarding the second dimension of gender mainstreaming, gender is mostly equated with the equal distribution of benefits to men and women in a particular economic sector rather than paying attention to deeper gendered dynamics in the sector. For instance, what gendered representations and constructions explain why the cassava sector is mainly occupied by men, and what kind of power relations are produced through such representations?

In Indonesia, meanwhile, international organisations more tightly connect economic issues and conflict. Both UN Women and UNDP have implemented projects addressing women's economic empowerment in conflict-affected regions of the country. UN Women has worked in many areas of Indonesia, but suffers from a lack funding and is dependent on project-related financing. ${ }^{2}$ As a result of a shift in donor interest towards preventing/countering violent

2 At the time of writing, its projects in Indonesia were funded primarily by Japan. 
extremism $(\mathrm{P} / \mathrm{CVE})$, programmes are currently implemented exclusively in Java, to the detriment of other post-conflict regions such as Maluku or Aceh. One project, squarely focused on $\mathrm{P} / \mathrm{CVE}$, links women's economic empowerment and social cohesion:

The project begins from the premise that women can be powerful partners in fighting violent extremism. It investigates the impact that women's economic empowerment and their leadership and participation in local communities can have on social cohesion and efforts to challenge extremist ideology and related violence.

TRUE, 2018, 4, author's emphasis

Regarding the first dimension of gender mainstreaming, gender clearly lies at the heart of such kinds of programming. On the second dimension, however, these conceptualisations strongly encapsulate what feminist scholarship has criticised in the integration of gender into P/CVE programmes: the essentialist way in which women are depicted as mothers, sisters, and daughters, and the instrumentalist ways in which women are presented as intrinsically powerful actors for changing behaviour, ultimately bearing responsibility for countering radicalisation in their environment (Giscard d'Estaing, 2017; Ní Aoláin, 2016). Such tensions are well illustrated, for instance, in the following excerpt from a brief of the above-mentioned project:

In fact, women can play a vital role in preventing the spread of extremist ideology and activity. As community leaders, professionals, and as mothers, wives, sisters and daughters in family settings, women shape the values of their community members. Their roles are multifaceted and include shaping community and family values, influencing decision-making of potential recruits, identifying and intervening at the early signs of radicalization that lead to extremism.

TRUE, 2018, 5, author's emphasis

Illustrating the challenges of addressing intersectional feminist concerns in the global security agenda, this UN Women programme (even though it was advised by recognised feminist scholars) hence had difficulty departing from the essentialist equation of gender with women, and from the instrumentalist conception of women as resources for preventing and countering violent extremism.

While the connection of peacebuilding to women's economic empowerment appears promising in this project, from the perspective of analysing 
gender mainstreaming's third dimension, it produces various unintended results. First, it seems to remain within a neo-liberal imaginary, as economic empowerment was translated mostly into 'support to saving-loan schemes and women's business development through women's cooperative groups' (CuevaBeteta, 2018, 2). Second, as pointed out by postcolonial critical analysts and feminists alike CVE agendas tend to stigmatise specific (religious, ethnic) communities while silencing other (such as white supremacist) forms of violence (Barkawi and Laffey, 2006; Giscard d'Estaing, 2017; Ní Aoláin, 2016; Schmid, 2016). The stigmatisation of Islam in IO s' CVE programmes becomes particularly problematic when implemented in a country that is majority Muslimas is the case in Indonesia-since it can contribute to crystalising and reifying religious identities, create tensions within and across groups, or leave the local peace activist and beneficiaries as sceptics or as simply opposed to the programmes. Third, the prioritisation of $\mathrm{P} / \mathrm{CVE}$ and the refocusing of peacebuilding programmes to Java has financially starved activities in post-conflict settings such as Aceh, Maluku, or Sulawesi. Yet communities in Maluku interviewed in the context of this research emphasised that their regions and cities were in a state of 'negative peace' (Rigual and Rahmawati, 2019). There may be no eruption of violence, but neighbourhoods and villages are now segregated as a result of the ethno-religious conflict between Christians and Muslims (1999-2003), and people still do not feel comfortable crossing into neighbourhoods inhabited by the other group (Rigual and Rahmawati, 2019). Thus, although economic and political elements of peacebuilding were rhetorically integrated into the UN Women P/CVE project in Indonesia, it seemed to fall short of managing complexities that result from its embeddedness in economic and security orthodoxies, as well as in donor fashions.

To bring more depth to the analysis of the different dimensions of gender mainstreaming in economic peacebuilding programmes, the next section provides an examination of the UNIDO/ILO Pela Gandong project-implemented in Maluku from 2009 to 2012-that includes the perspective of its beneficiaries. Like the UN Women $\mathrm{P} / \mathrm{CVE}$ project, it integrated peacebuilding and economic reconstruction into its design, but started from a development logic.

\section{4 \\ The Unido/ILo Pela Gandong Project as an Example of a Gendered 'Peace through Development' Approach}

Like UN Women in Nigeria, UNDP Indonesia adopts a strong commitment to bottom-up approaches in the design of activities, running workshops with conflict-affected populations at the outset of each project, with the goal of 
assessing needs and specific pathways towards peacebuilding for communities. The 'Peace through Development' (PTD) programme is particularly emblematic of the way in which UNDP has connected economic development and peacebuilding. ${ }^{3}$ As noted by the programme officer interviewed, the goal was less income generation than 'creating social cohesion' (interview with UNDP programme officer, Jakarta, 19 October 2017). The programme supported micro-production from local resources by providing material and training for the creation of local co-operatives. The peacebuilding component lay in the co-operation that was required across religious communities in neighbouring villages.

The Pela Gandong project followed a 'Peace through Development' design, and received some funds and training from UNDP. It was jointly implemented by the ILO and UNIDO and like the UN Women project was otherwise funded by Japan. An assessment of local resources and of the preferences of the communities in Maluku led to a focus on the production of nutmeg juice; participants would jointly collect the nutmeg and then produce the juice. The name of the project is borrowed from a tradition in Maluku, the Pela Gandong, a form of 'cooperation and brotherhood' tying two men from different villages across religious differences (Rahmawati and Udasmoro, 2015; UNIDO, MPG and ILO, 2012) (author's emphasis).

As noted by one of the UNIDO officers responsible for the project's implementation, the gender component of the initiative did not necessarily exist from the outset, but arose during the first stages of the implementation phase. Indeed, the officer noted that

Tradition of women in Maluku to support the economy for their family is very strong, especially traditionally. [...] And that is why when we introduced a programme to the selected villages, there was a huge interest of the women, the mothers, and some young women to be involved in the project because, I mean, especially for the villagers, they are so keen to help with additional income for the family. It's somehow, [...], it's easier to work with them instead of ... sometimes the men, the bapak [the men] [...] it's a bit difficult for them to be involved.

Interview with UNIDo programme officer, Jakarta, 19 October 2018

3 For more information on this project and on its successor, 'Peace through Development in Disadvantaged Areas', see the dedicated UNDP webpage (UNDP Indonesia, 2016) as well as the final evaluation report, produced by Universitas Gadjah Mada (UNDP Indonesia and Gadjah Mada University, 2012). 
One of the UNIDO officers in Maluku supported this view, and further explained why women ended up being strongly involved in the project's implementation:

We concentrated mostly on women, because there was one statement we believed greatly, 'If women are successful, then the family is prosperous'. That was one of our points in intervention, working with women. That's why, in the groups, women were more productive. Those who dropped out of school and had no work, they were the ones we recruited as our participants. Interview with UNID o programme officer, Maluku, 14 October 2017

During a test phase of the microfinance projects, the projects' officers saw women as more committed than men. The idea of integrating more systematically women more systematically was hence adopted for the implementation phase.

We made a microfinance group, and we made groups for men and for women. So, of about 30 groups, five of them were men's, while the rest were women. The women's groups all succeeded, but only one of the men's groups succeeded. We investigated it further and we found that the money we'd given had been used to buy cigarettes, etc. So they were not productive, and this answered our hypothesis, that women would automatically bring prosperity to their families.

Interview with UNIDO programme officer, Maluku, 14 October 2017

These stories illustrate two little-explored elements of gender mainstreaming in economic peacebuilding. First, in contrast to headquarter strategy documents, Io s do not systematically integrate gender into the design and implementation of their programmes. In the case of the Pela Gandong project, women were integrated into the project from the bottom up without this being anticipated in the design. Second, and pertaining to the second dimension of gender mainstreaming, the stories confirm the well-known finding that gender is frequently equated with women in development and peacebuilding programmes. Moreover, the two project officers construct stereotypical identities of women and men, portraying women as diligent, serious, committed and responsible in their use of their income while depicting men as less involved, not caring, reluctant to participate in women's groups, less responsible in their spending, and hence less 'successful' and 'productive' in the microfinance and micro-production groups set up by UNIDO. This informed how the Pela Gandong initiative targeted beneficiaries and explains why the projects ultimately ended up focusing specifically on women. Conversely, as an 
unintended effect the initiative itself further reinforced existing understandings of Malukan 'machismo', forgoing an opportunity to challenge patriarchal gender relations. A more fine-grained gender analysis could have asked where men's reticence came from, and how gender norms could be problematised to perhaps mitigate their reproduction.

Also important to emphasise here, from a third-dimension perspective, is the influence of neo-liberal thinking. This appeared in the economic goals of the project, which focused on inserting the beneficiaries into market-oriented production and international value chains, without further exploration of the way in which this suited the modes of livelihood and development priorities of conflict-affected communities. It also appeared in the way the project judged success. While the economic effectiveness of the programme was not considered central in the design of the initiative, the assessment of success nevertheless employed the neo-liberal standard of productivity. Conversely, the role of the programme in decreasing inter-group tensions received little attention in assessments in spite of the fact that peacebuilding was a key component in the design of the project.

What were the effects of these arguably problematic approaches to gender mainstreaming for the beneficiaries of the Pela Gandong project? One of the co-operatives set up by the project was still in existence during our fieldwork. Fifteen women actively ran the co-operative, even though men sometimes contributed to some tasks. In interviews the women told us that their lives had changed in several ways. First, they were glad to have earnings, which allowed them to contribute to household incomes and be more independent financially and hence socially. Asked how they used the additional income generated by the co-operative, the women answered as follows:

First, it's got its own power, because if we ask for it from our husbands ... even if we earn only a little, at least we make it ourselves. If our children go to school in the morning, usually we'd ask our husbands, but with this money we don't need to ask them anymore.

FGD, beneficiaries of the UNIDO-UnDP Pela Gandong project, Toisapu, 16 October 2017

Women hence describe the freedom they feel due to the opportunity to possess their own money and to use it for small, everyday expenses for their families without having to always ask their husband. Surpassing the amount spent or the fact that they now are in charge of spending some of their money to support their children, women describe their sense of autonomy in being able 
to act without needing to ask, without being dependent on their husband's willingness to share money.

Second, the project also enhanced women's mobility and their confidence. They mentioned that before the project they had mostly been confined to their homes and kitchens, but that the implementation of the co-operative-from training to the installation of the production material to the running of all the aspects of production - led them to meet other people, to travel to Jakarta, to work outside the home:

Before there was this group, our work was only in the kitchen, but after the group was formed we have often gone out for our activities and as such if something happens in the family, we have the confidence necessary to explain it. For example, if our husbands are wrong, we'll explain things and try to help our husbands fix their mistakes. With training, we've become braver, more confident in speaking. At first I was surprised ... Oh, I can talk like that? But over time our husbands could listen and understand.

FGD, beneficiaries of the UNIDO-UNDP Pela Gandong project, Toisapu, 16 October 2017

Thus, participating in the running of the co-operative did more than just improve women's income; it also empowered them to speak up. This perception was supported by another respondent:

Yes, it's true that, by often taking part in training activities, this has broadened our horizons and so we are more confident in voicing our opinions. Where before we were only in the kitchen and taking care of our children, by taking part in activities where we meet with outsiders, we've gained greater knowledge and that's made us believe in ourselves more. Because none of us have received much of an education, never gone to university.

FGD, beneficiaries of the UNIDO-UNDP Pela Gandong project, Toisapu, 16 October 2017

Men are usually not involved in the everyday running of the co-operative, but they contribute if needed, by means that are in some cases indeed challenging existing gendered representations and role distributions:

Because [of] our activities here, in handling the nutmeg, sometimes the men help us by taking care of the children at home. Sometimes if there are problems, like the machines breaking down, we need the men to 
come and help fix them. Whatever happens, we still require our husbands' assistance.

FGD, beneficiaries of the UNIDO-UnDP Pela Gandong project, Toisapu, 16 October 2017

Women thus are not only empowered to speak up at home, it appears that the project also disrupted traditional gender divisions of labour in the household.

Yet this initiative did not change masculinist decision-making processes within the village. As noted by one of our respondents, 'We're always there, but our influence and our voices as women have yet to be given attention' (FGD, beneficiaries of the UNIDO-UndP Pela Gandong project, Toisapu, 16 October 2017).

In spite of this continuing dynamic, a UNIDO officer insisted that there had also been change in decision-making at the village level, suggesting that it has 'improved local wisdom. It has improved their relationship, improved their strength, what you call it ... their confidence, self-esteem. So they [the women] are able to speak out loud on their own behalf'.

He went on to recount an anecdote in which the women had not received promised machinery from the head of the village:

Then, $[\ldots]$ suddenly the women went the office and they talked ... to the raja [king] or kepala desa [village head] [...] 'Why don't you ever get ...' They're questioning. They're complaining. And, there is some equipment or some tools have been missing. Then suddenly they go to the head office and they check one by one and then suddenly they ask 'where is this item? We haven't seen this item'.[...] So, they are complaining. And then the officer goes back and ... I don't know whether they bought the new one or ... But at least there is confidence for them to go ask ... to protest ...

Interview with UNIDo programme officer, Jakarta, 19 October 2018

Their voices may not be heard as a matter of routine, but clearly these women have gained the confidence to claim entitlements.

Even though women were an afterthought in the Pela Gandong project, the gender implications of the project were significant for the beneficiaries we interviewed, generating both economic and political empowerment. The stereotyping of women as successful and men as lazy and the neo-liberal focus on productivity may have contributed to women's sense of entitlement, given their success, regardless of the narrow focus on efficiency and the possibly essentialising effects of gender stereotyping. We are left to wonder what might have been possible had a more considered approach to gender mainstreaming 
been adopted from the start. We also have to acknowledge that out of the various small co-operatives implemented in Ambon (around 20 in the context of this project) very few persisted or fulfilled their 'peacebuilding' objectives. Several community members in other villages informally reported to our team of local researchers not having seen their trust in their neighbours improve as a result of the project, and worrying about the sustainability of the programme's results.

The WPS agenda is widely recognised for successfully mainstreaming gender into the field of security, but also for stopping short of transformative effects and for neglecting the economic dimension of peace. Seeking to bring further empirical insight to feminist research on WPS, this chapter developed a three-dimensional approach to analyse how gender has informed, shaped, and affected (and was in turn affected by) economic peacebuilding in Indonesia and Nigeria.

Regarding the first dimension, it is noticeable that there is a good adoption overall of gender mainstreaming in official documents, with adaptations and different forms of prioritisation of the WPS agenda in documents produced in headquarters. But this does not translate evenly into programme reports and implementations. While UN Women embraces a focus on women and gender and the issue is central to its programming, UNDP has struggled to keep gender in focus in both case countries. Interestingly, the bottom-up design of projects by both UN Women and UNDP and in-depth consultations to allow affected populations to voice their needs and priorities at the outset of projects have resulted in a focus on women where this was not originally envisioned. Nevertheless, as various scholars have noted previously, gender is often still missing from the implementation phase of projects. In the UNDP project in Nigeria and the UNDP/UNIDO project in Indonesia, gender was not considered central at the stage of programme design.

When it comes to the second dimension of gender mainstreaming, the examples presented here show that gender is still often equated with women in economic peacebuilding strategic documents and programmes. In the UNDP/ UNIDO programme in Indonesia, as much as in the UN Women programmes in both countries, what mattered was whether women were involved, whether they benefited from projects, and whether there was an increase in women's participation at the end of the project. This is obviously not an issue in and of itself, but as often noted by critics of gender mainstreaming it can become 
a problem when the project inadvertently reproduces unequal gender norms and reifies gender stereotypes. Moreover, it is a problem when projects fail to address these in a gender analysis and forgo the opportunity to disrupt these norms and stereotypes during their implementation.

As illustrated in the case of the Pela Gandong project, gender representations and norms are productive: they inform, drive, guide and shape peacebuilding programming. First, the gender representations of policy officers and those conveyed by beneficiaries during consultation processes were taken for granted rather than reflectively explored, hence reinforcing existing stereotypes. Women's and men's represented roles served as a baseline for the design of the project, which then was assessed against these pre-existing arrangements. Gender stereotypes informed the design and implementation of the project, with women generally perceived as committed, serious, and responsible and men pictured as not interested and not serious when it comes to spending. The project failed to address these gender stereotypes.

On the other hand, in spite of multiple criticisms, these programmes also have positive effects. The UN Women project in Nigeria showed that a significant disruption of patriarchal institutions can be accomplished when women's empowerment is at the centre of project designs. Following the interventions of the project, women are now part of traditional leadership structures in the Jos Plateau. Yet even when women become the focus in a less planned manner, as in the Pela Gandong project in Maluku, they reported feeling greater entitlement, more autonomous regarding their income and spending, and empowered to speak for themselves if needed, and have experienced changes in their everyday lives, allowing them to shift their activities from the household to public spaces. At the same time, the more formal power structures of the community regarding, for instance, political representation have not changed much following the project, since existing gender representations remained unaddressed. A similar pattern emerged from the UN Women project in northern Nigeria, where the inclusion of women in traditional leadership councils—considered a huge success by the programme officer-might mask tokenism and a failure to assess ingrained gendered resistances.

Finally, regarding the third dimension of gender mainstreaming in economic peacebuilding I have highlighted the productive power of neo-liberal framings and of approaching insecurity in terms of violent extremism and the associated shift in the allocation of resources. Neo-liberal biases lead to a privileging of logics of productivity with regard to the goals of projects as well as to measurements of success. In addition, the shift of funding from targeting postconflict peacebuilding to countering violent extremism risks the sustainability 
of peace in post-conflict contexts as attention moves away from fragile situations where ethno-religious divisions have become entrenched.

Overall, examples of gendered economic peacebuilding programmes in Indonesia and Nigeria bring as much hope as they generate concern. Smallscale transformations perceived as positive by women are underway, but multiple and overlapping challenges will remain as long as projects continue to equate gender with women and to impose neo-colonial and neo-liberal market-oriented economic models for peacebuilding programming. Reflexivity and the co-constitution of knowledge and design with potential beneficiaries, both before and after projects, hold the promise of further removing the topdown reproduction of power relations, as well as the external imposition of neo-liberal economic agendas and stereotypical gendered constructs.

\section{References}

Achakpa, M. and J. Onyesoh (2018) 'Gender Dimensions of Social Conflict, Armed Violence and Peacebuilding': Phase 2 Report on Selected Peacebuilding Institutions on the Plateau, Nigeria (Abuja).

Almagro, M.M. de and C. Ryan (2020) 'Introduction: (Re)Integrating Feminist Security Studies and Global Political Economy: Continuing the Conversation through Empirical Perspectives', Politics \& Gender, 16(3), DoI: 10.1017/S1743923X200o032X.

Baliamoune-Lutz, M. and M. McGillivray (2009) 'Does Gender Inequality Reduce Growth in Sub-Saharan African and Arab Countries?', African Development Review, 21(2), pp. 224-242, DOI: 10.1111/j.1467-8268.2009.00209.x.

Barkawi, T. and M. Laffey (2006) 'The Postcolonial Moment in Security Studies', Review of International Studies, 32(2), pp. 329-352, DoI: 10.1017/So260210506007054.

Basu, S. (2017) 'The UN Security Council and the Political Economy of the WPS Resolutions', Politics \& Gender, 13(4), pp. 721-727, DoI: 10.1017/S1743923X1700037X.

Bowen, D.L., V.M. Hudson and P.L. Nielsen (2015) 'State Fragility and Structural Gender Inequality in Family Law: An Empirical Investigation', Laws, 4(4), pp. 654-672, DoI: 10.339o/laws4040654.

Caprioli, M. (2005) 'Primed for Violence: The Role of Gender Inequality in Predicting Internal Conflict', International Studies Quarterly, 49(2), pp. 161-178, www.jstor.org/ stable/3693510.

Chinkin, C. and H. Charlesworth (2006) 'Building Women into Peace: The International Legal Framework', Third World Quarterly, 27(5), pp. 937-957, DOI: 10.1080/ o1436590600780391. 
Chisholm, A. and S. Stachowitsch (2017) '(Re)Integrating Feminist Security Studies and Feminist Global Political Economy: Continuing the Conversation', Politics \& Gender, 13(4), pp. 710-715, DOI: 10.1017/S1743923X17000356.

Cohn, C. (ed.) (2012) Women and Wars: Contested Histories, Uncertain Futures, 1st edition (Cambridge, UK; Malden, MA: Polity).

Cohn, C. (2011) “"Feminist Security Studies”: Toward a Reflexive Practice', Politics \& Gender, 7(4), pp. 581-586, DoI: 10.1017/S1743923X11000389.

Collier, P., V.L. Elliott, H. Hegre, A. Hoeffler, M. Reynal-Querol and N. Sambanis (2003) Breaking the Conflict Trap: Civil War and Development Policy (Washington, D.C.: World Bank and Oxford University Press), https://openknowledge.worldbank .org/handle/10986/13938 (accessed on 21 May 2017).

Cornwall, A., E. Harrison and A. Whitehead (eds.) (2006) Feminisms in Development: Contradictions, Contestations and Challenges (London: Zed Books).

Cueva-Beteta, H. (2018) Empowered Women, Peaceful Communities, Indonesia 2017-2018 (Jakarta: UN Women Indonesia).

De La Rey, C. and S. McKay (2006) 'Peacebuilding as a Gendered Process', Journal of Social Issues, 62(1), pp. 141-153, DOI: 10.1111/j.1540-4560.2006.oo443.x.

Dean, M. (2010) Governmentality: Power and Rule in Modern Society, 2nd edition (Los Angeles, London, New Delhi, Singapore and Washington, D.C.: SAGE).

Doyle, M.W. (1986) 'Liberalism and World Politics', The American Political Science Review, 80(4), pp. 1151-1169, DoI: 10.2307/1960861.

Duncanson, C. (2016) Gender and Peacebuilding (Hoboken: Wiley).

Forsberg, E. and L. Olsson (2016) 'Gender Inequality and Internal Conflict', Oxford Research Encyclopedias, Politics, DoI: 10.1093/acrefore/9780190228637.013.34.

Foucault, M. (2004) Sécurité, Territoire, Population (Paris: Le Seuil).

Giscard d'Estaing, S. (2017) 'Engaging Women in Countering Violent Extremism: Avoiding Instrumentalisation and Furthering Agency', Gender \& Development, 25(1), pp. 103-118, DOI: 10.1080/13552074.2017.1279823.

Greenberg, M.E. and E. Zuckerman (2009) 'The Gender Dimensions of Post-Conflict Reconstruction: The Challenges in Development Aid', in T. Addison and T. Brück (eds.) Making Peace Work: The Challenges of Social and Economic Reconstruction (Houndsmills and Basingstoke: Palgrave Macmillan and UNU-WIDER).

Hudson, H. (2012) 'A Double-Edged Sword of Peace? Reflections on the Tension Between Representation and Protection in Gendering Liberal Peacebuilding, International Peacekeeping, 19(4), pp. 443-46o,, DoI: 10.1080/13533312.2012.709753.

Hudson, V.M. and H. Matfess (2017) 'In Plain Sight: The Neglected Linkage between Brideprice and Violent Conflict', International Security, 42(1), pp. 7-4O, DOI: 10.1162/ ISEC_a_00289. 
Krause, J. (2018) Resilient Communities: Non-Violence and Civilian Agency in Communal War (Cambridge: Cambridge University Press), https://www.cambridge.org/core/ books/resilient-communities/818EE668DB9DF8F5 $\mathrm{B}_{766 \mathrm{CF}} 179624 \mathrm{BFC}_{4}$ (accessed on 19 May 2021).

Krause, K. and O. Jütersonke (2005) 'Peace, Security and Development in PostConflict Environments', Security Dialogue, 36(4), pp. 447-462, DOI: 10.1177/ og67010605060449.

Kunz, R. and E. Prügl (2019) 'Introduction: Gender Experts and Gender Expertise', European Journal of Politics and Gender, 2(1), pp. 3-21, DOI: info:DoI/10.1332/ 251510819X15471289106o77.

Marteu, E. (2011) 'Rethinking Extraversion: Uses of Empowerment, Gender, and Feminism in Bedouin Women's Organizations in the Negev (Israel)', Cultures \& Conflits, 83(3), pp. 57-77, DOI: 10.400o/conflits.18192.

Moser, C. (2005) 'Has Gender Mainstreaming Failed?', International Feminist Journal of Politics, 7(4), pp. 576-59o, DOI: 10.1080/14616740500284573.

Moser, C. and A. Moser (2005) 'Gender Mainstreaming Since Beijing: A Review of Success and Limitations in International Institutions', Gender \& Development, 13(2), pp. 11-22, DOI: 10.1080/13552070512331332283.

Newman, E., R. Paris and O.P. Richmond (eds) (2009) New Perspectives on Liberal Peacebuilding (Tokyo and New York: United Nations University Press).

Ní Aoláin, F. (2016) 'The "War on Terror" and Extremism: Assessing the Relevance of the Women, Peace and Security Agenda', International Affairs, 92(2), pp. 275-291, DOI: 10.1111/1468-2346.12552.

Paris, R. (2010) 'Saving Liberal Peacebuilding', Review of International Studies, 36(o2), pp. 337-365, DoI: 10.1017/So26o210510000057.

Prügl, E. (2011) 'Diversity Management and Gender Mainstreaming as Technologies of Government', Politics \& Gender, 7(1), pp. 71-89, Do I: 10.1017/S1743923X10000565.

Prügl, E. (2009) 'Does Gender Mainstreaming Work?', International Feminist Journal of Politics, 11(2), pp.174-195, DoI: 10.1080/14616740902789542.

Prügl, E. and J.A. Tickner (2018) 'Feminist International Relations: Some Research Agendas for a World in Transition', European Journal of Politics and Gender, 1(1-2), pp. 75-91, DOI: 10.1332/251510818X15272520831193.

Rahmawati, A. and W. Udasmoro (2015) Background Research Paper on Gender, Conflict and Peacebuilding in Maluku, unpublished background paper for the Gender Dimensions of Social Conflict, Armed Violence and Peacebuilding project (Geneva: The Graduate Institute and $\mathrm{R}_{4} \mathrm{D}$ ).

Ramnarain, S. (2013) 'The Political Economy of Peacebuilding: The Case of Women's Cooperatives in Nepal', The Economics of Peace and Security Journal, 8(2), DOI: $10.15355 /$ epsj.8.2.26. 
Reysoo, F. and C. Verschuur (eds.) (2017) Genre, mondialisation et pauvreté, Cahiers genre et développement, 3 (Geneva: Graduate Institute Publications), http://books .openedition.org/iheid/5505 (accessed on 11 September 2018).

Rigual, C. (2018) 'Rethinking the Ontology of Peacebuilding. Gender, Spaces and the Limits of the Local Turn', Peacebuilding, 6(2), pp. 144-169, DoI: 10.1080/ 21647259.2018.1453640.

Rigual, C. and A. Rahmawati (2019) Making Peace Sustainable? From Successful Policies to Concerns for Peace in Maluku, Indonesia, Research Brief 1 (Geneva and Bern: Gender Centre, The Graduate Institute and Swiss Programme for Research on Global Issues for Development), https://www.graduateinstitute.ch/library/ publications-institute/making-peace-sustainable-successful-policies-concerns -peace-maluku (accessed on 19 May 2021).

Rigual, C., W. Udasmoro and M. Achakpa (forthcoming) 'Social Criticism as Peacebuilding? Gendered Mechanisms of Conflict Management in ResourceDriven Tensions, Enugu and East Java'.

Schmid, A.P. (2016) 'Research on Radicalisation: Topics and Themes', Perspectives on Terrorism, 10(3), pp. 26-32, www.jstor.org/stable/26297594.

Sjoberg, L. (2009a) 'Introduction to Security Studies: Feminist Contributions', Security Studies, 18(2), pp. 183-213, DoI: 10.1080/og6364109029oo129.

Sjoberg, L. (ed.) (20ogb) Gender and International Security: Feminist Perspectives, 1st edition (London and New York: Routledge).

True, J. (2018) Empowering Women for Peaceful Communities: Evidence from Indonesia and Bangladesh, Research Brief (Bangkok: UN Women Regional Office for Asia and the Pacific), https://asiapacific.unwomen.org/en/digital-library/publications/2018/ o6/evidence-from-indonesia-and-bangladesh (accessed on 19 May 2021).

True, J. (2016) 'Explaining the Global Diffusion of the Women, Peace and Security Agenda', International Political Science Review, 37(3), pp. 307-323, DoI: 10.1177/ 0192512116632372.

True, J. (2011) 'Feminist Problems with International Norms: Gender Mainstreaming and Global Governance', in J.A. Tickner and L. Sjoberg (eds.) Feminism and International Relations: Conversations About the Past, Present and Future (New York: Routledge), pp. $73^{-88 .}$

UNDP Indonesia (United Nations Development Programme) (2016) The Peace Through Development in Disadvantaged Areas (PTDDA), (Jakarta: UNDP), https://www .id.undp.org/content/indonesia/en/home/operations/projects/crisis_prevention_ and_recovery/the-peace-through-development-in-disadvantaged-areas--ptdda.html (accessed on 10 May 2021).

UNDP Indonesia and Gadjah Mada University (2012) Final Evaluation. Peace Through Development (PTD) Project (Jakarta and Yogyakarta: UNDP and Gadjah Mada 
University), file:///Users/marenschulte/Downloads/PTD_eval\%2oreport_CSPS_ \%2oto\%2O_ERC.pdf (accessed on 19 May 2021).

UndP Nigeria (2013) Roadmap Nigerian Agribusiness Supply Development Program (Abuja: UNDP), https://www.ng.undp.org/content/nigeria/en/home/library/poverty/ AgroBusi.html (accessed on 19 May 2O21).

UNIDO, MPG, and ILO (United Nations Industrial Development Organization, Maluku

Province Government, and International Labour Organization) (2012) UNIDOILO Pelagandong Project: Realizing Minimum Living Standards for Disadvantaged Communities Througn Peace Building and Village Based Economic Development (Jakarta: UNIDO and ILO), https://www.ilo.org/wcmsp5/groups/public/---asia/--ro-bangkok/---ilo-jakarta/documents/publication/wcms_318403.pdf (accessed on 19 May 2O21).

UNRISD (United Nations Research Institute for Social Development) (2005) Gender Equality: Striving for Justice in an Unequal World. Policy Report on Gender and Development: 10 Years after Beijing (Geneva: UNRISD/UN), http://www.unrisd.org/

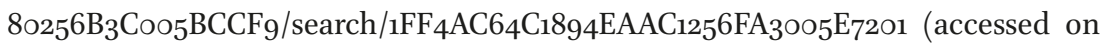
5 March 2018).

Verschuur, C. (2017) Expertes en genre et connaissances féministes sur le développement: Qui sait? (Paris: Editions L'Harmattan), DoI: 10.400o/books.iheid.6895. 